\title{
Expectation and Reality: the Situation of Constructions Sites of the Ministry of Education in Brazil
}

\author{
Tany Ingrid Sagredo Marin \\ Campus Capanema, Universidade Federal Rural da Amazônia \\ Rua João Pessoa, 340, Capanema-PA, 68700-030, Brazil \\ Ana Caroliny Conde Lopes \\ Campus Capanema, Universidade Federal Rural da Amazônia \\ Rua João Pessoa, 340, Capanema-PA, 68700-030, Brazil \\ Alexandre Rodrigues Serra \\ Campus Capanema, Universidade Federal Rural da Amazônia \\ Rua João Pessoa, 340, Capanema-PA, 68700-030, Brazil
}

Received: Aug. 9, 2018 Accepted: Sep. 7, 2018 Online published: Sep. 20, 2018

doi:10.5296/jpag.v8i3.13485 URL: https://doi.org/10.5296/jpag.v8i3.13485

\begin{abstract}
In 2015, the Ministry of Education (MEC) created the Integrated Monitoring and Control System (SIMEC), an operational and management tool that shows the situation of education-related constructions under city hall management on their website. The city hall managers fill the information on the system. Therefore, we wonder if the constructions' situation pointed out by Simec reflects their real conditions. The research aims to learn the real situation of constructions described on Simec using on-site survey, observation, photographic record, and, whenever possible, using mobile applications like "Tá de Pé" (It's on) from "Transparência Brasil" (NGO) or "Eu Fiscalizo" (I supervise) from Federal General Accounting Office (a.k.a TCU in Brazilian Portuguese acronym) to send the findings. We inspected nineteen construction sites in four cities in the State of Pará. The results indicate that the situation of most of them (11 of 19) does not correspond to the information filled by the public agents in Simec. The situation indicates an absence of internal controls in MEC during the supervision of the constructions sites. Thus, we want to
\end{abstract}


raise awareness about the change that can be made in society by engaged and empowered actors of social control.

Keywords: theory of the firm, ministry of education, integrated monitoring and control system (Simec), supervision, applications, apps

\section{Introduction}

The Theory of the Firm applied to the public sector assumes the existence of a contract between society (principal) and the government (agent). The principal pays taxes so that the agent performs actions for the well-being of the population. However, the individualist interest of the agent impairs the efficiency of the agency (Slmoski, 2009; Costa, Leite, \& Campos, 2015).

This agent-principal relationship is impaired by the existence of information asymmetry, as stated in Theory of the Firm applied to public administration, regarding the possible inappropriate behaviors of the agent. At the same time, the citizen is unaware of the public agents' actions, therefore, is at the mercy of their acts and control (Araújo \& Sanchez, 2005).

The asymmetry of information becomes even worse in an environment that lacks internal controls since the agent controls this system. The agent is the one who will make decisions that will affect society or otherwise. Therefore, it is necessary to supervise their actions through an adequate and effective internal control.

However, the damage of the absence of internal controls could be minimized with the advent of the "Lei de Transparência" (Transparency Act, Law number 131/2009 - Brasil, 2009) and the "Lei de Acesso à Informação" (Information Access Act, Law number 12.527/2011 Brasil, 2011). These laws require all expenditure information to be published in real time at a visible and easily accessible place via the transparency portals. It is expected that these laws will contribute to a better performance of social control with a less complicated and less bureaucratic supervision of the principal on the agent's actions.

Specifically, the Federal Government, through the Ministry of Education (MEC), has created the Integrated Monitoring and Control System (SIMEC), an operational and management tool that shows the situation of education-related constructions under city halls management on their website, which can be accessed by any citizen (MEC/FNDE, 2017). Then again, it is important to point out that city halls' managers insert the information in the system.

Considering that, we raise the doubt: does the expectation correspond to reality? More specifically, does the situation of the constructions sites pointed out by Simec demonstrate the real state in which those constructions are?

With that information in mind, the main objective of this study is to learn the real situation of constructions described on Simec using on-site survey, observation, photographic record; and, whenever possible, using mobile applications, like "Tá de Pé" (It's on) by "Transparência Brasil" (NGO) or "Eu Fiscalizo" (I supervise) by Federal General Accounting Office (aka TCU in Brazilian Portuguese acronym) to send the findings. 


\section{Ml Macrothink}

Journal of Public Administration and Governance

ISSN 2161-7104

2018, Vol. 8, No. 3

Our motivation was based on our concern to find out the state of public schools constructions, by checking the information provided by the public agents in Simec against reality.

An adequate school environment can mean increased chances of learning and opportunities for children. However, when schools buildings remain unfinished, those constructions adversely affect the development of that community, contributing to the increase in school dropout rates, illiteracy, and marginalization.

The study becomes even more relevant because our supervision is performed on poor and small cities that depend mostly on federal resources. Therefore, the expected outcome of showing society the reality of these constructions is to create awareness and interest in performing social control.

\section{Theoretical Foundation}

\subsection{Theory of the Firm}

Considering the ideas of Slmoski (2009) and Costa et al. (2015), where Theory of the Firm applied to the public sector comprehends the existence of a contract in which the society (principal) expects, as a compensation for paying taxes, that the government (agent) will perform functions that would address society's needs. Frequently, the agency's efficiency is impaired by public managers that do not prioryze citizen's needs, but their personal or group interests.

In relationships that seek profit, it is essential to address the Theory of the Firm as a determinant factor in the study of the processes related to public or private administration. Even though the profit is measured differently in the public sector, assuming that the demands of society are met, a fact that makes the national state indispensable (Matias-Pereira, 2005).

The application of the Theory of the Firm, in the public administration, takes place with three fundamental factors, according to Siffert Filho (1996) apud Slomski (2009): the possible behaviors to be adopted by the public agent; the actions of this public agent affect the interest of both parties involved; and above all, the citizen is unaware of the actions of this public agent, which the author refers to as information asymmetry.

The information asymmetry is evident when Araújo and Sanchez (2005,p. 145) state the following "the control system is only for those who control it and not for those that want to control it." Since the citizens do not get the information they need to exercise control, they are excluded from social control by those who can control. Consequently, it is clear that the public agent will make decisions that will affect the interest of society, without any participation of citizens.

Specifically, regarding the construction of public buildings, the agent can choose those that will be beneficial to them at that moment, leaving aside those that would be of upmost importance for the population. That demonstrates the Brazilian political culture is still focused on the functional prerogatives of satisfaction of the personal interests of the agents 
while complying with the legislation that protects public interests is left aside (Santos, 2014).

With that concept in mind, we conclude that, on the act of the public agent lies the need to supervise the processes that culminated in the decisions taken by the agent, that is, an adequate and effective internal control. In addition, there is the administrative principle of Transparency, which ensures the regular inspection by the one who is the most interested in the results of the decisions of the public agent: the citizen.

Therefore, the ineffectiveness of internal control instruments reflects on the problem of information asymmetry. In this regard, the following item discusses the main aspects of this inefficiency, revealing the need to maintain mechanisms to control the acts of public agents.

\subsection{The Absence of Internal Control}

The Federal Constitution of 1988 (Brasil, 1988), in articles 31, 71 and 74, addresses two forms of control for public activities: internal and external control. The latter is the responsibility of the National Congress with the assistance of the Federal General Accounting Office (a.k.a TCU). On the other hand, the Executive, Legislative and Judicial branches, within the structure of each entity sustain the internal control (Brasil, 1988).

While external control limits its supervision to verify the compliance of support documentation (invoices, contracts, orders, etc) with rules and laws compliance, the internal control is managed and executed by each entity, that should support external control, and has the duty of assure the right execution of public policies, evaluate and supervise the use of public resources (Arruda \& Teles, 2010).

Despite its fundamental role, internal controls suffer with a cultural issue from agents that rather keep information with them and do not inform citizens, perpetuating a continuous flow of corruption and inefficiency. Thus citizens lack access to public goods and services to which they are entitled (Arruda \& Teles, 2010).

Consequently, Araújo and Sanchez (2005) state that internal controls are pro-forma: it is verified simply if the expenses are compliant with the accounting processes. In other words, there is no way to validate if the agents are fulfilling their role of administering public expenses and generating trust and confidence in the effectiveness and efficiency of the public resources use.

Specifically, the lack of this control in city hall managed constructions occurs from the moment of contracting with high investments. According to Lage (2017), high-cost constructions are not executed efficiently, due to the lack of planning and monitoring, resulting in poor quality constructions. The situation worsens when there is a lack of internal control and transparent data for citizens regarding the use of resources, since, as general media often reports, many public buildings constructions are begun but never completed.

\subsection{Transparency as a Tool for Social Control}

Social Control is the action of society in the control and supervision of Public 
Administration acts. According to the "Escola Nacional de Administração Pública" (National Public Administration School, a.k.a. ENAP) (ENAP, 2015), social control is performed by the citizens supervising the application of public resources and the implementation of public policies, seeking that the Administration meets the interest of the common good.

Public transparency is fundamental for more effective social control because with more information available, more the population can ask, participate on monitoring public management, and demand from the government that is obliged to offer a better service to the population. This way, government is closer to society, and a more efficient, responsible and transparent management is built. The same way, an empowered society that can participate more effectively in social control (UNDP, 2006) is also created, and can contribute to tackle the corruption and inefficiency actions of unprepared agents (Arruda \& Teles, 2010).

With Transparency (Brasil, 2009) and Access to Information (Brasil, 2011) Acts, social control became easier to achieve, since their advent, the actions of the society in public agents supervision became less complicated and less bureaucratic. After all, such laws determine that all expenses shall be published, including staff payroll, balance sheet, budget and patrimonial information of cities, purchases/bidding processes, and accountability in real time at a visible and easily accessible place, among other measures.

The opening of government data shows a change in the structure, which is now based on the tripod: transparency, participation, and collaboration. Which are able to provide transparency, improvements in social control and citizen participation (Matheus, Ribeiro, $\&$ Vaz, 2012). This tripod is supported by information and communication technologies (ICTs) disseminated mainly in social media and in the connectivity of mobile devices (O'Reilly, 2011).

Technology can be a great ally when society acts as supervising entity of public authorities with mobile applications, such as those indicated by Ministry of Transparency and Comptroller General of Brazil (a.k.a CGU) (CGU, 2017):

- $\quad$ "Vidinha de balada" (Party Life) that provides the quality of the expenses of Congress representatives;

- "Minha Cidade" (My City) that shows the situation of resources distribution and priority degree, making it possible to identify misuse in public spending;

- $\quad$ "Folha Limpa" (Clean Sheet) that identifies disagreements and illegal accumulations of public positions in the payroll of the state and municipal employees;

- "Tá de Pé" (It's on), which allows monitoring the construction of schools and daycare centers with funds transferred from the federal government under the management of City halls;

- $\quad$ "Eu Fiscalizo" (I Supervise), which allows sending of statements regarding various categories, including health, education, constructions, security, transportation, 


\section{Macrothink}

Journal of Public Administration and Governance

ISSN 2161-7104

2018, Vol. 8, No. 3

purchase/bidding process, and environment, as well as adding photos and/or files in PDF for evidence.

Since $92,1 \%$ of Brazilians home have access to internet through its mobile phone (Brasil, 2016), these mobile tools provide citizen an opportunity to inspect public administration in real time only with the use of a smartphone or tablet, making them protagonist of the possibility of significant changes in society through their active participation.

\section{Methodological Procedures}

\subsection{Sample}

The first phase of the data collection used the Simec (MEC/FNDE, 2017), an operational and management tool of MEC that provides the situation of the constructions under city halls management in their website. In this web portal, it is possible to check the situation of constructions sites in a certain city or download a spreadsheet with the information of all the constructions, as shown in Figure 1.

Simec was created on July 15, 2015, to assist in the elaboration of the Articulated Actions Plan (PAR), responsible for monitoring and budgeting the federal government proposals online in the area of education. The information in the system is filled by City halls employees and can be accessed by any citizen (MEC/FNDE, 2017).

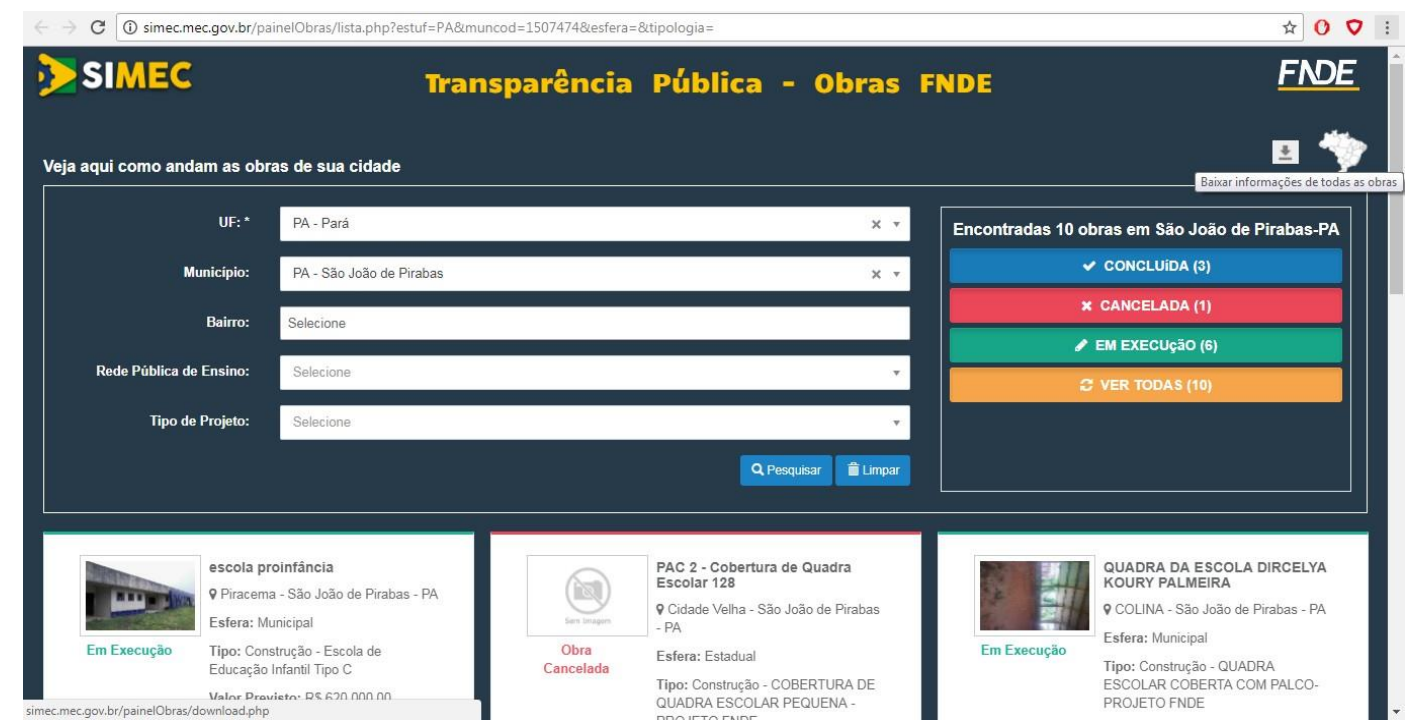

Figure 1. Portal Simec as an instance of the situation of the MEC's construction sites in the city of São João de Pirabas dated of September 30, 2017.

Source: MEC/FNDE, 2017

In Simec spreadsheet, constructions are organized by situation statuses, such as: completed, contracted, reformulation, ongoing, unfinished, in bidding process, canceled, paralyzed and proposer's planning (MEC/FNDE, 2017). 
Our sample was based on the Simec spreadsheet of September 30, 2017, we selected four types of construction situations: ongoing, canceled, paralyzed and completed. This selection was necessary, since, the study depends on the physical existence of a construction site for photographic record. Besides, the other situations (contracting, reformulation, bidding process and proposer's planning) are related only to bureaucratic/paperwork steps, before there is any construction per se.

After construction situations were defined, we have elected construction sites on the following cities: Bonito, Capanema, Nova Timboteua and São João de Pirabas. These cities are located in the northeastern region of the State of Pará, and we have chosen them for convenience.

Those cities can be classified as poor, small and dependent on funds transferred from State and Federal governments. The average Gross Domestic Product (GDP) of these cities is $\mathrm{R} \$ 7$ 548.35/inhabitants., while the national average is $\mathrm{R} \$ 26$ 441.76/inhabitants. The population size varies from 14942 to 67150 inhabitants (IBGE, 2010). They still have low tax collection on their own, and depend on funds transferred from federal and state governments for education, health and security actions, among others (Portal ORM, 2018).

Moreover, Brocco et al (2018) state that citizens with better conditions of health, education and good jobs, have better conditions to carry out municipal social control.

\subsection{Procedures}

We surveyed nineteen constructions between November 25, 2017, and January 13, 2018, distributed among the four cities in the sample, according to Table 1:

Table 1. Situation and quantity of constructions, by cities in the sample, based on data from Simec on September 30, 2017.

\begin{tabular}{|c|l|c|}
\hline City & \multicolumn{1}{|c|}{$\begin{array}{c}\text { Construction site } \\
\text { situation }\end{array}$} & $\begin{array}{c}\text { Qty of } \\
\text { construction sites }\end{array}$ \\
\hline \multirow{2}{*}{ Bonito } & Ongoing & 1 \\
\cline { 2 - 3 } & Completed & 1 \\
\hline \multirow{2}{*}{ Capanema } & Ongoing & 3 \\
\cline { 2 - 3 } & Completed & 1 \\
\hline \multirow{2}{*}{ NovaTimboteua } & Ongoing & 3 \\
\cline { 2 - 3 } & Completed & 6 \\
\hline \multirow{2}{*}{ São João de Pirabas } & Ongoing & 3 \\
\cline { 2 - 3 } & Completed & $\mathbf{1 9}$ \\
\hline \multicolumn{2}{|c|}{ TOTAL } & \\
\hline
\end{tabular}

Source: Prepared by the authors with information from MEC/FNDE (2017).

The cities of the sample, on the date of the survey, had only construction sites with "ongoing" and "completed" situations, and, for each one of them, we have performed an on-site survey using observation, photographic record, and also, where possible, mobile 


\section{Macrothink}

Journal of Public Administration and Governance

ISSN 2161-7104 2018, Vol. 8, No. 3

apps as "Tá de Pé" by Transparência Brasil (NGO) or "Eu Fiscalizo" by Federal General Accounting Office (a.k.a TCU).

The app "Tá de Pé" was launched in April 2017 by the Non-Governmental Organization (NGO) Transparência Brasil and aims to supervise the construction of public schools with federal resources under the responsibility of city halls throughout Brazil. The app provides the location of construction sites with Global Positioning System (GPS) and provides information on the expected completion of this construction; see Figure 2 (Transparência Brasil, 2017).

The user can inspect a construction site, send photos from their smartphones and if there are indications of delay, the NGO Transparência Brasil will contact the responsible City Hall. If the City Hall does not provide an explanation within 15 days, the Federal Government, responsible for the transfers of funds, will be notified by the NGO (Transparência Brasil, 2017).

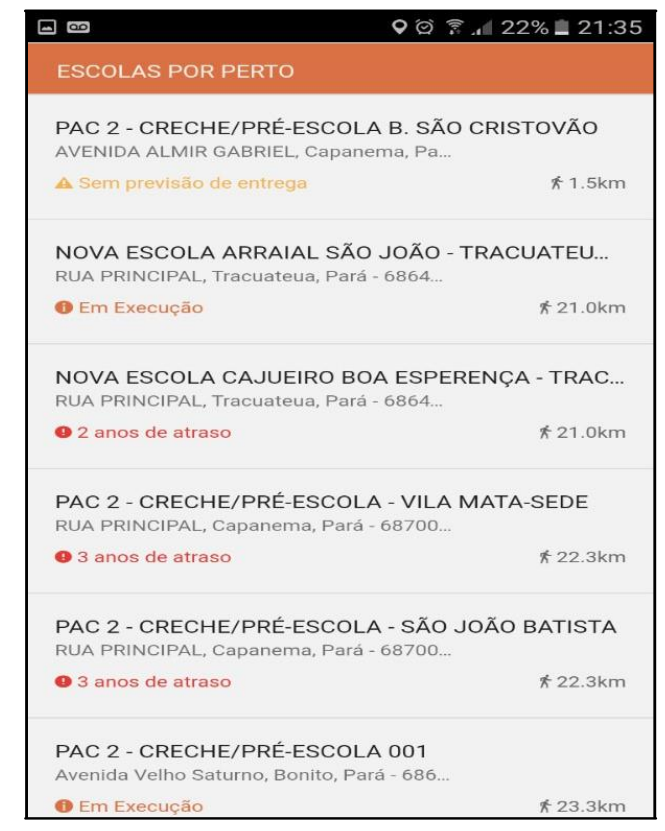

Figure 2. Home screen of "Tá de Pé" app.

Source: Research Data.

The app "Eu Fiscalizo" was launched by the TCU in June 2016, and with the option "cadastrar informação" (register a statement), as per Figure 3, it allows the citizen's contribution to the monitoring of the use of resources coming from the Federal Union (TCU, 2016). 


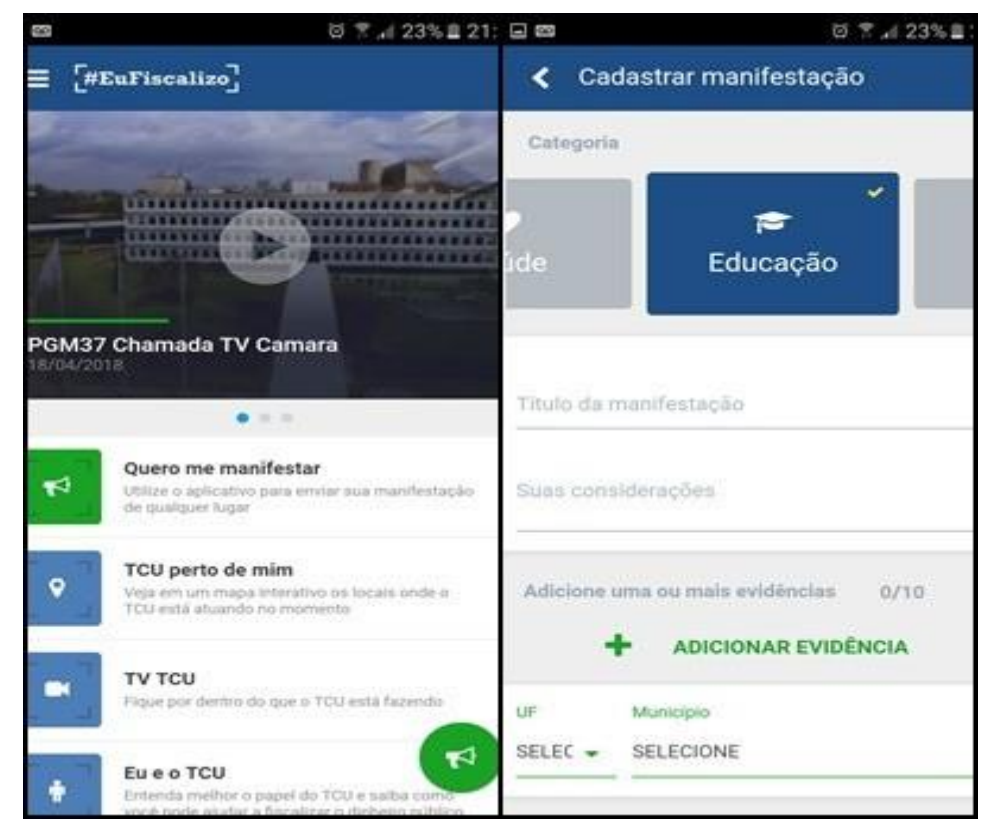

Figure 3. Home screen and register statement option of the app "Eu Fiscalizo" by TCU. Source: Search data.

With this application, citizens can express themselves wherever they are; they can also include photographic records to support their statement, in addition to follow its progress, this way; they can put in practice the social control.

\section{Results}

The survey of the 19 construction sites required a trip of approximately 450 kilometers, at certain times, through small dirt roads with difficult access. The addresses of the construction sites as informed by the Simec were also a difficult point, since they were imprecise, in a way that the support of residents of the localities was constantly needed to find the exact location of the constructions.

The results are presented according to the two types of situation of the surveyed construction sites: completed and ongoing constructions.

\subsection{Completed Buildings}

After the inspection of the six constructions with "completed" status according to Simec Spreadsheet, we verified that $100 \%$ of these constructions actually reflected the situation described by the agents of the involved City Halls. Figure 4 shows two examples of this category. 


\section{Macrothink}

Journal of Public Administration and Governance

ISSN 2161-7104 2018, Vol. 8, No. 3

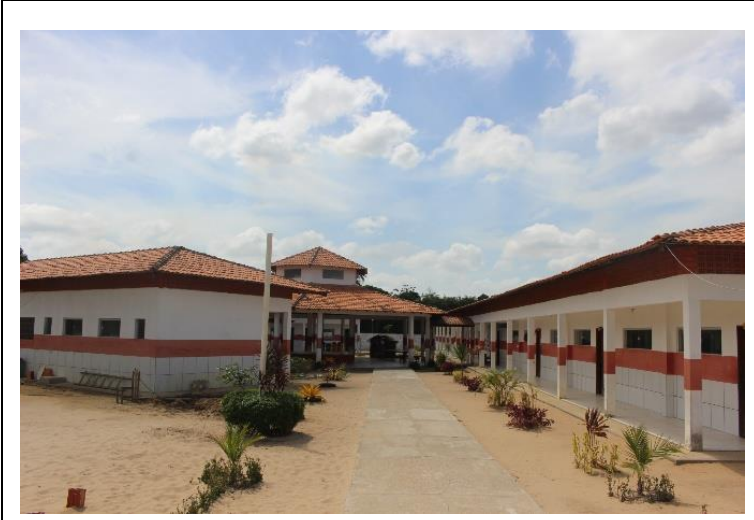

School Maria Amélia - Nova Timboteua

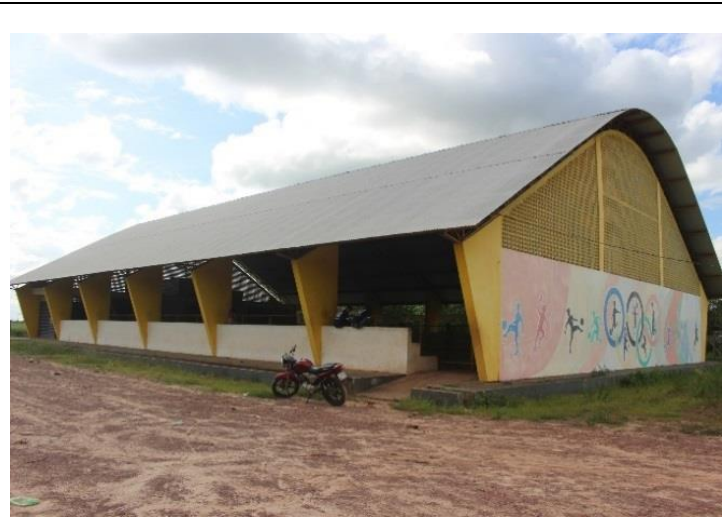

Sports Court Alzenir Farias - Bonito

Figure 4. Examples of completed buildings.

Source: Research data.

We have noticed that although the buildings were delivered, some of them were deteriorated, such as the construction of six classrooms in São João de Pirabas, completed in May 2015, and the daycare center Alzenir Farias in August 2016, which, besides the deterioration, had their lamps stolen according to information from the daycare staff. Figure 5 shows such structure problems.

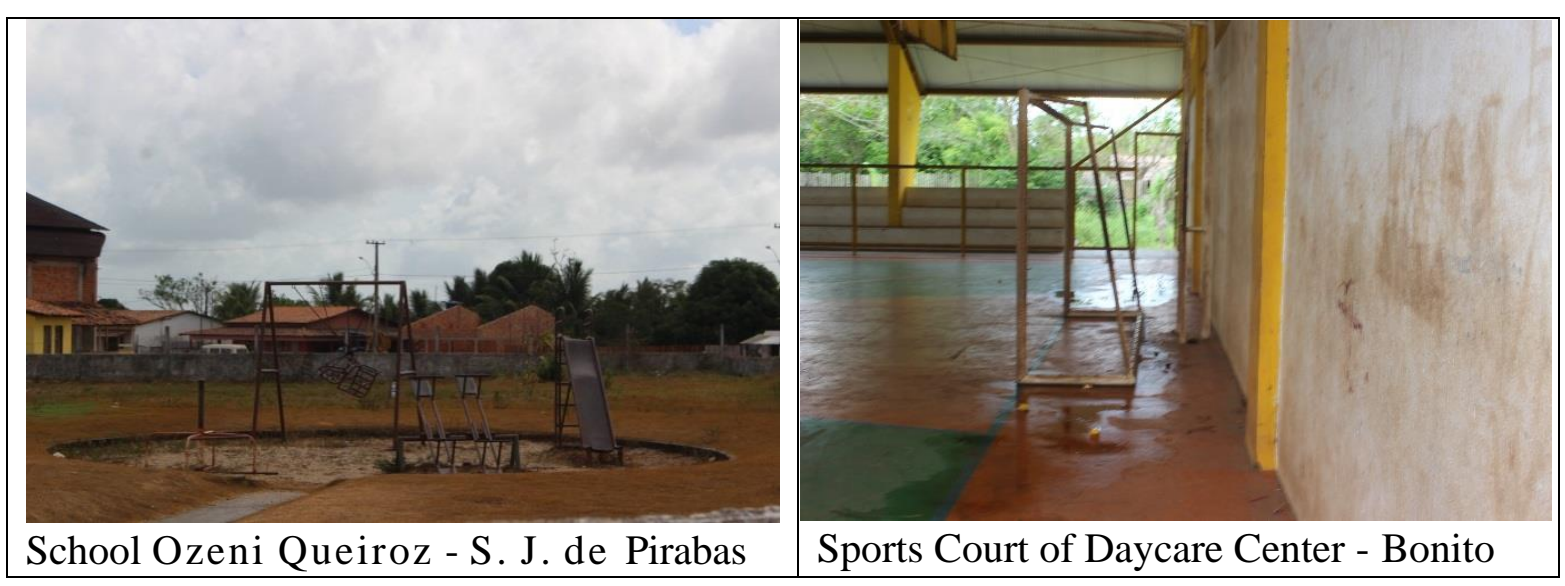

Figure 5. Examples of completed, however, deteriorated buildings in November/December 2017.

Source: Research data.2017.

In summary, those buildings are completed, which generates benefits for the students and the population of the town in general, but they need permanent maintenance, since they indicate the low quality of the construction work, corroborating with Lage (2017) that states this fact to be a consequence of the lack of planning and monitoring.

\subsection{Ongoing Constructions Works}

For the inspection of the 13 works with status as "ongoing" the apps "Tá de Pé" and "Eu Fiscalizo" were used, the results show that only two construction sites marked with that 
situation in Simec Spreadsheet had actually an ongoing construction work.

\subsubsection{Supervision Using the App "Tá de Pé"}

By using this app, it was possible to inspect three constructions sites, all located in São João de Pirabas, as shown in Figure 6, which illustrates the upload of the survey.

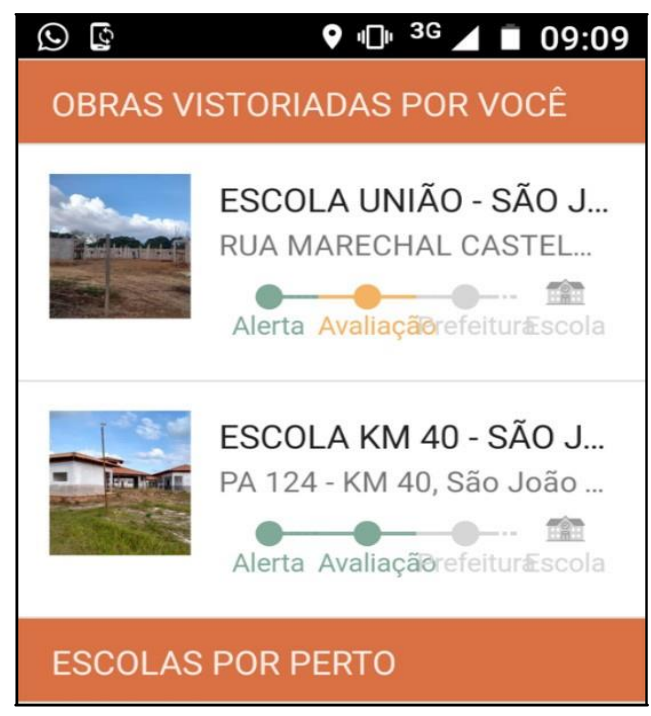

Figure 6. Upload of the survey of construction sites using the app "Tá de Pé" in November/2017.

Source: Research data

Amongst these three works, two were actually ongoing construction sites, as shown in Figure 7. However, they are running late when compared to the delivery date reported by both the Simec Spreadsheet and the application. When local residents were inquired about the delay, they responded it was related to the slow pace of the work.

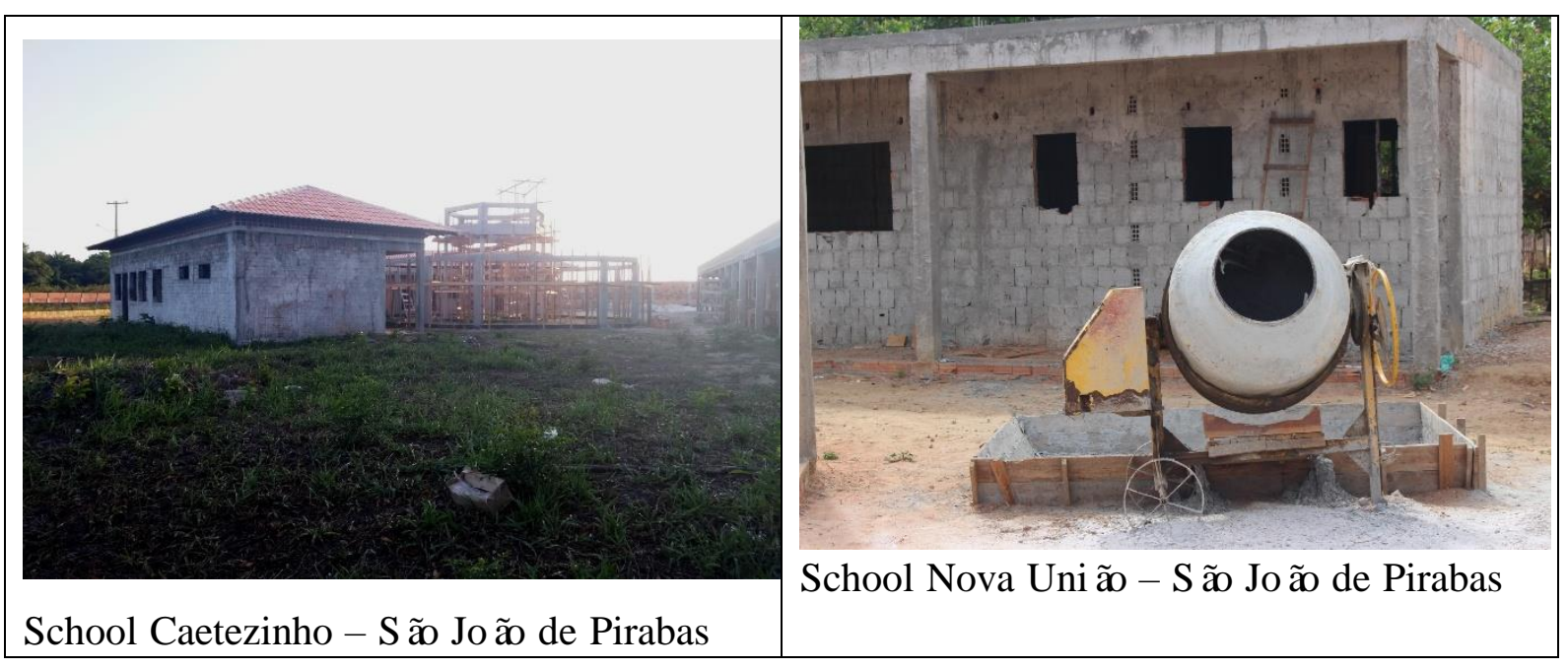

Figure 7. Ongoing construction sites inspected using the app "Tá de Pé" in November/2017. 


\section{Macrothink}

Source: Research data.

Regarding the other construction site, a school building in the $\mathrm{Km} \mathrm{40,} \mathrm{its} \mathrm{current} \mathrm{situation} \mathrm{is}$ abandonment as illustrated in Figure 8. After uploading the survey to "Tá de Pé" in November 2017, City hall was contacted. As there was no response from city hall during the time stipulated by the NGO Transparência Brasil, the Ministry of Transparency and Comptroller General of Brazil (a.k.a CGU), an internal control body of the Federal Government, was contacted for an explanation.

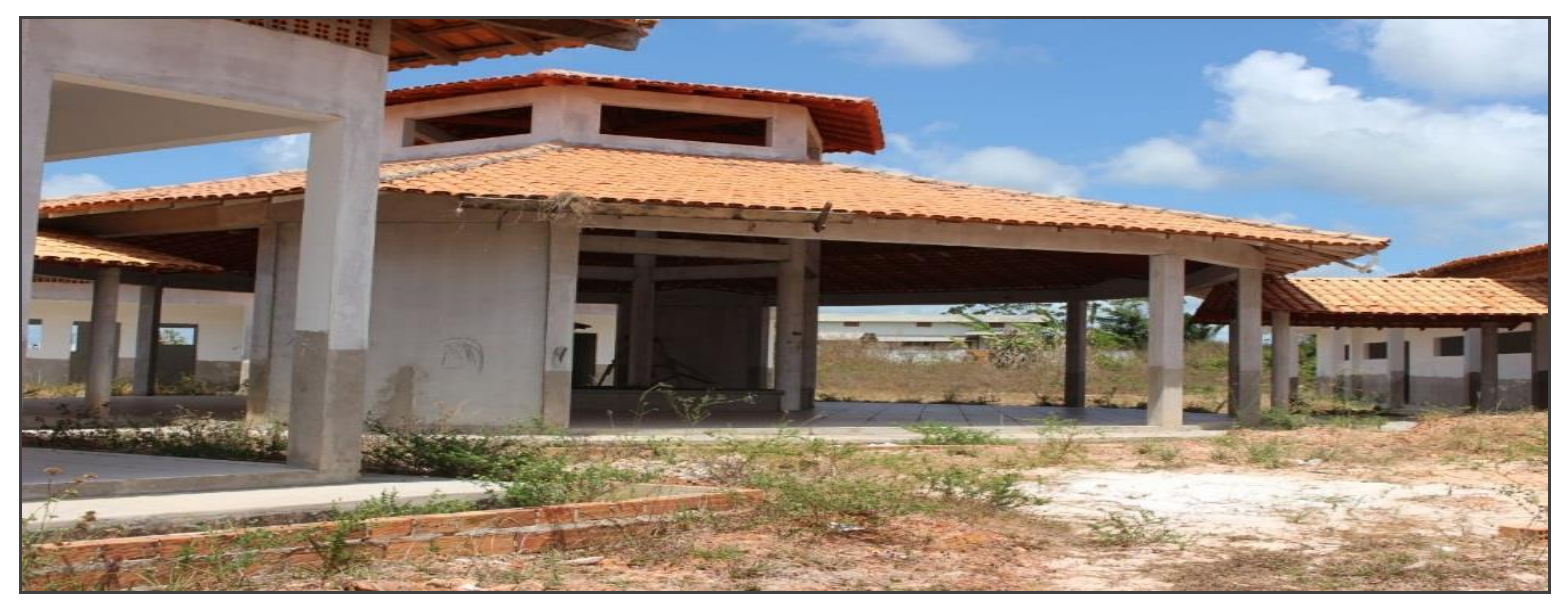

Figure 8. Abandoned construction site of a school on Km 40 in São João de Pirabas, inspected using the app "Tá de Pé" in November/2017.

Source: Research data.

The CGU's response came on the app itself, according to Figure 9; they presented a new deadline for completing the construction work and stated that the agreed Term of Commitment is in force.

However, the situation is worrisome, even though $80 \%$ of the total budget for the construction was already transferred and $81 \%$ of the building is constructed, it was possible to observe that the building has been robbed and vandalized.

This situation can mean that more money than what was planned would be necessary to complete this construction, or as often it is covered by media that many public buildings constructions are begun but never completed. Leading to a situation where no public service is offered, children without classes, and the indispensable, according to Matias-Pereira (2005), national state fails to meet society basic needs. 


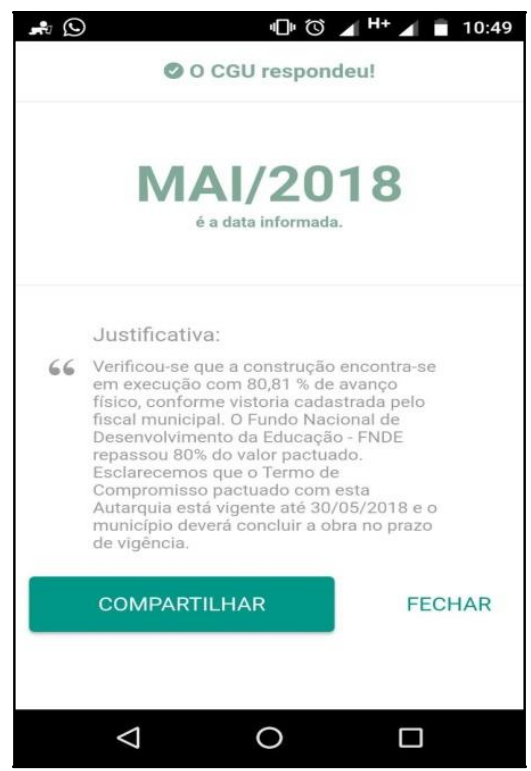

Figure 9. CGU response on the app "Tá de Pé" in January/2018 regarding the survey carried out in the school on Km 40 in São João de Pirabas.

Source: Research data.

\subsubsection{Ongoing Construction Works Inspected Using the App "Eu Fiscalizo"}

Amongst the other ten ongoing construction works that should be supervised by the app "Eu Fiscalizo," it was possible for the research team to send only one statement regarding the school "Proinfância" in São João de Pirabas. Figure 10 shows the upload of the statement, no response was received from the app in the stipulated 15 days time.

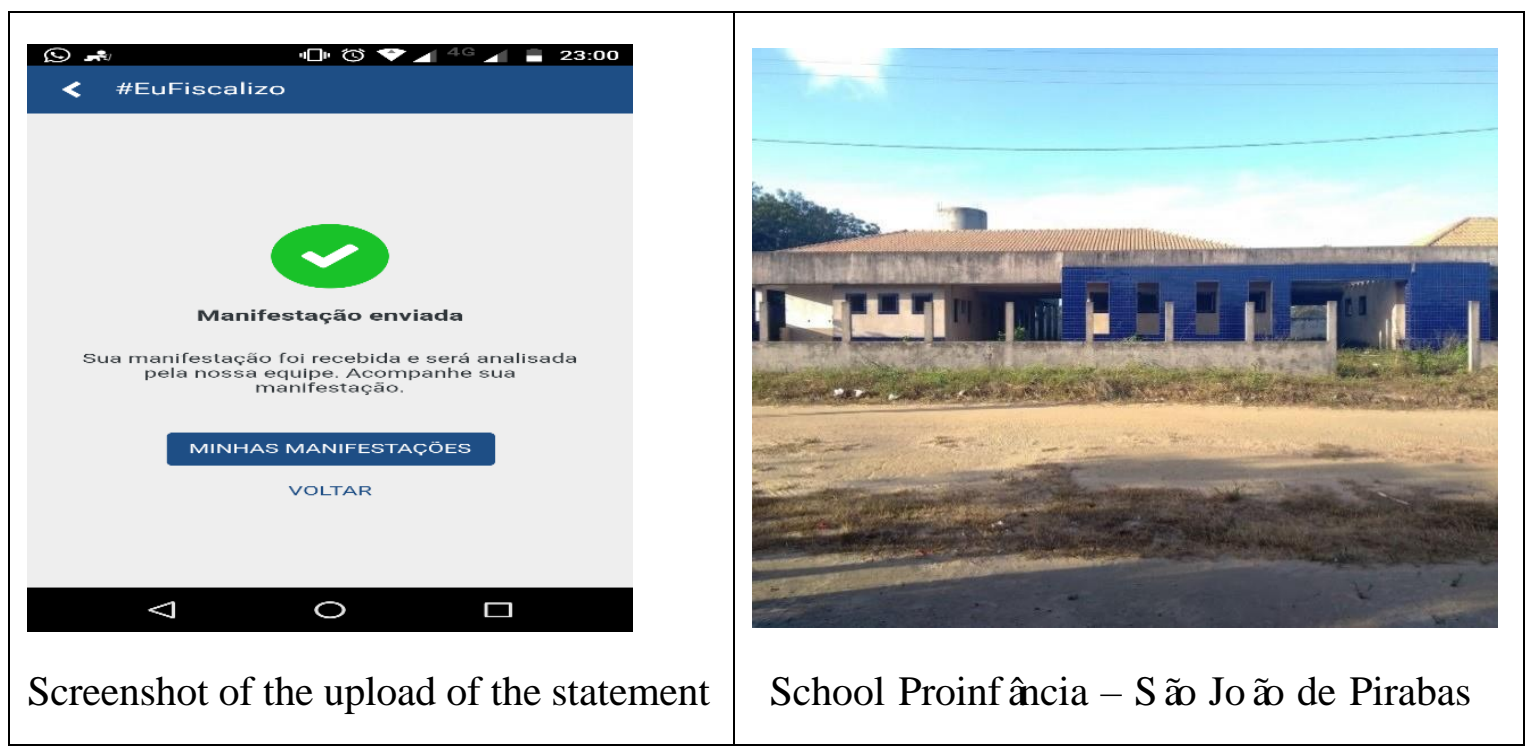

Figure 10. Upload of statement and photo to the app "Eu Fiscalizo" regarding

"Proinfância" school in São João de Pirabas on November/2017.

Source: Research data. 


\section{Macrothink}

Journal of Public Administration and Governance

ISSN 2161-7104

2018, Vol. 8, No. 3

For the other nine construction sites, during the upload of the statement, the app presented an error as shown in the smartphone screenshots in Figure 11. Through the TCU's ombudsman channel, the error was reported, but there was no conclusive answer.

As it was stated at the theoretical foundation TCU primary role is to analyze documentation, the creation of this app is new and we believe is an attempt to bring society closer to public management, even though, there are still technical challenges to be overcome. But, it could also mean that the agents still need to overwhelm the cultural issue of keeping information with them as indicated by Arruda and Teles (2010).

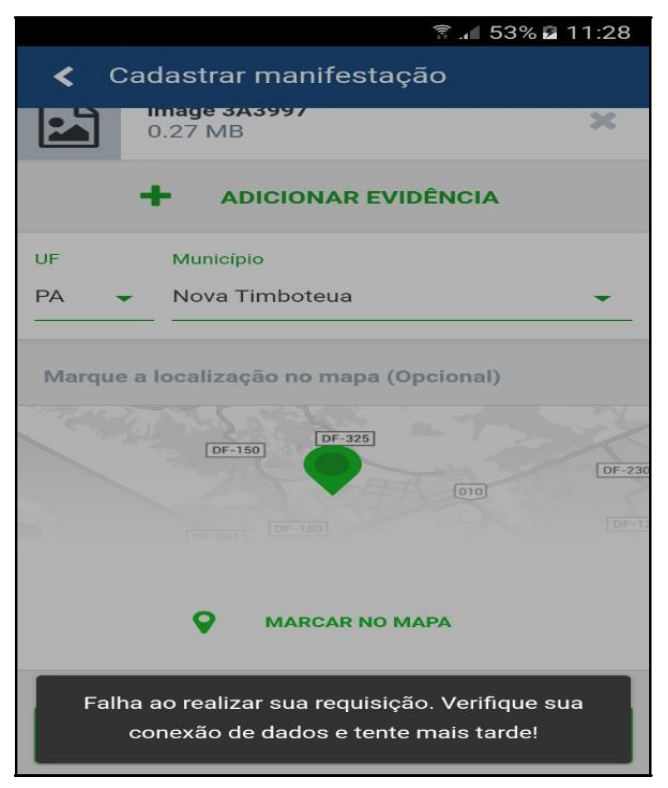

Figure 11. Error during attempt to upload a statement with "Eu Fiscalizo" application by TCU in November/2017.

Source: Research data.

Therefore, these nine works were inspected, but there is no real time statement regarding them. An e-mail was sent to "Tá de Pé" and another to "EuFiscalizo," as instructed by NGO Transparência Brasil and TCU.

In general, what we could verify on these other ten construction sites marked as "ongoing" were total abandonment, as shown in Figure 12. 


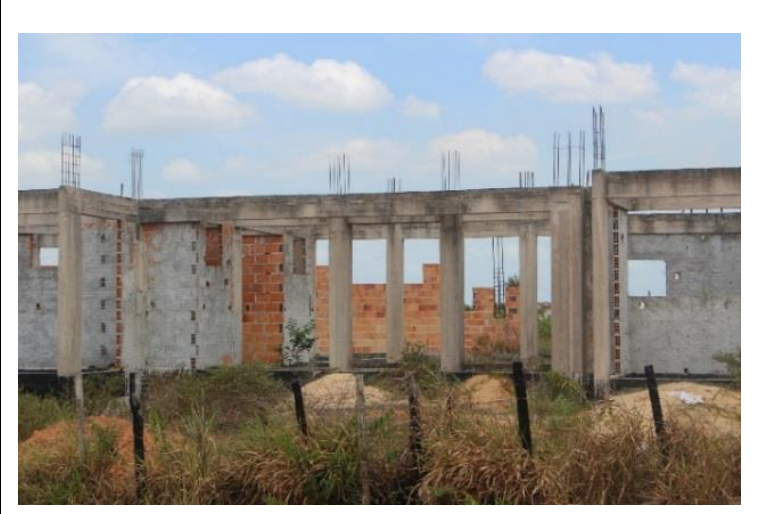

Day Care Center - Nova Timboteua

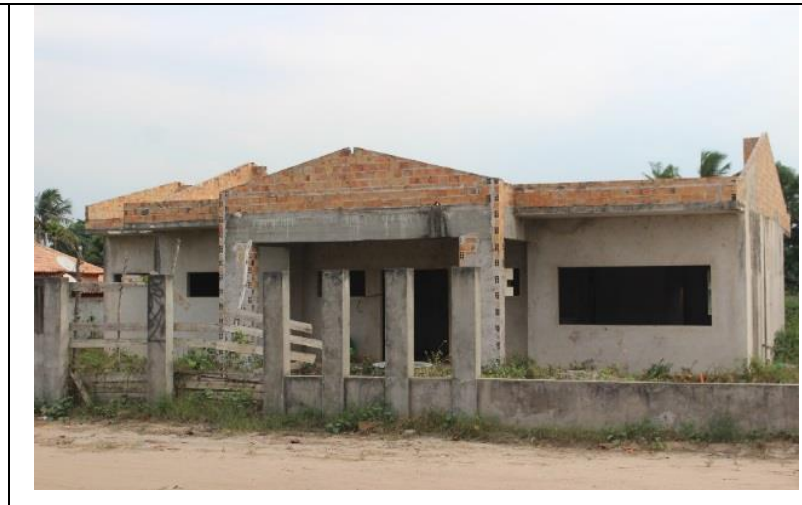

Day Care Center/ Pre School - Bonito

Figure 12. Two examples of the ten construction sites that are listed as "ongoing" on Simec, but that are actually abandoned.

Source: Research data.

The results show that $84.62 \%$ of the construction works with the status of ongoing are in fact paralyzed.

When questioned employees of the two schools in the city of Capanema, they said that because of the change of government on City hall, the constructions of Júlia Guerreiro School and Olga Pereira School sports courts were paralyzed. This fact corroborates with the findings in Santos (2014), stating that Brazilian politics is still focused on personal interests of the agents, in this case, the City hall managers that have chosen to complete works that would be personally beneficial at that moment, leaving aside those that would be extremely necessary for the population.

This fact lead us to a couple of important questions: although The Brazilian law on access to information brought public data and information, the public agent still delivers the information that best suits their interests? And, is this an example of internal controls pro-forma? As it was suggested by Araújo and Sanchez (2005), where it is not possible to validate if the agents are fulfilling their role of administering public expenses and generating trust and confidence in the effectiveness and efficiency of the use of public resources.

Our results reflect the findings of Arruda and Teles (2010) and Araújo and Sanchez (2005), as we are faced with an absence of internal controls and unprepared agents, who only have reported what was convenient for them.

Moreover, our findings are consistent with Brocco et al (2018), how state that social control is better performed at cities with greater development. As our work took place at poor towns, it seems that this is a favorable environment for maintaining the terrible cycle of corruption and inefficiency.

Because of that, we consider that our work is not just an academic research, but it intends to bring attention to an important opportunity of mobilization of social control throughout a simple app at vulnerable places that can make a difference in the future of children's 
education.

\section{Final Considerations}

We have sought, through this research, to confront the information provided by the public agents on Simec against the reality, for that we have performed surveys on construction sites of education-related buildings that were funded by the Federal Government. In addition, when possible, we have used mobile applications to send the findings to the control bodies.

We have observed that the situation of most of these construction sites (11 of 19) did not correspond to the information filled by the public agents in Simec. Therefore, expectation does not reflect reality.

We found during on-site surveys, observation and photographic record, that these 11 construction sites marked as "Ongoing" on Simec were paralyzed. That reflects total neglect with the population and waste of public money. Some construction works were in the final phase, and even then, they were paralyzed, left at the mercy of vandals, robbers, and used as a shelter to street people and drug users.

On the other hand, three works with the status of completed on Simec were effectively completed. The delivery of these buildings certainly brought benefits to the population in need. However, it was observed the necessity of maintenance of these building, although they are brand new constructions, they are quite deteriorated and already needing repairs, which indicates the poor quality of the material used or the service.

The use of mobile applications has increased a lot in recent years, and the trend is that with the advancement of technology, these tools become fundamental pieces of social control. However, there is the need to improve the applications, especially "Eu Fiscalizo" of by TCU, which presented failures during the research.

On a general note, the absence of internal controls of MEC in the supervision of the construction works published by Simec was noted. Since the information inserted by the City halls, public agents on Simec portal did not reflect the reality of the construction sites. The importance of the role of the principal (society) as a control agent was verified, for enabling the improvement of public services.

This situation reinforces the importance of the role of the principal (society) as a control agent was verified, for enabling the improvement of public services, in this case of an adequate school environment, that can mean increased chances of learning and opportunities for children.

With this fact, our aim is to encourage more citizens to act as a control agent, by using their smartphone, they could enable to measure in real time the application of public resources and the implementation of public policies, bringing a better world for tomorrow.

It is important to highlight the importance of the University's role as a member of society to encourage the use of new technologies that allow social control and its improvement. This role of the University is fundamental mainly in remote areas in which the majority of the 
population lacks higher levels of education.

At the moment, it was not possible to measure the social impact caused by the surveys and the related report to the control bodies, using the apps, but this is a suggestion for future research, as well as expanding the sample and carrying out the study in other locations.

\section{References}

Araújo, M., \& Sanchez, O. A. (2005). A corrupção e os controles internos do estado. Lua Nova, 65, 137-73. https://doi.org/10.1590/S0102-64452005000200006

Arruda, A. M. F., \& Teles, J. S. (2010). A importância do controle social na fiscalização dos gastos públicos. Revista Razão Contábil \& Finanças, 1, jul./dez.

Brasil. (1988). Constituição da República Federativa do Brasil. Brasília, DF: Senado Federal: Centro Gráfico, 292 p.

Brasil. (2009). Lei Complementar $n^{\circ} 131$, de 27 de maio de 2009. Acrescenta dispositivos à Lei Complementar no 101, de 4 de maio de 2000, que estabelece normas de finanças públicas voltadas para a responsabilidade na gestão fiscal e dá outras providências, a fim de determinar a disponibilização, em tempo real, de informações pormenorizadas sobre a execução orçamentária e financeira da União, dos Estados, do Distrito Federal e dos Municípios. Diário Oficial [da] República Federativa do Brasil, Brasília, 28 de maio de 2009.

Brasil. (2011). Lei $\mathrm{n}^{\mathrm{o}}$ 12.527, de 18 de novembro de 2011. Regula o acesso a informações previsto no inciso XXXIII do art. 5o, no inciso II do $\S 30$ do art. 37 e no $§ 20$ do art. 216 da Constituição Federal; altera a Lei no 8.112, de 11 de dezembro de 1990; revoga a Lei no 11.111, de 5 de maio de 2005, e dispositivos da Lei no 8.159, de 8 de janeiro de 1991; e dá outras providências. Diário Oficial [da] República Federativa do Brasil, Brasília - DF, 18 de novembro de 2011.

Brasil. (2016). Instituto Brasileiro de Geografia e Estatística. Pesquisa nacional por amostra de domicílios: síntese de indicadores 2015. Rio de Janeiro: IBGE.

Brocco, C., Grando, T., Quadros Martins, V., Junior, A. C. B., \& Corrêa, S. (2018). Transparência da gestão pública municipal: Fatores explicativos do nível de transparência dos municípios de médio e grande porte do rio grande do sul. REVISTA AMBIENTE CONTÁBIL-Universidade Federal do Rio Grande do Norte-ISSN 2176-9036, 10(1), 139-159. https://doi.org/10.21680/2176-9036.2018v10n1ID12040

CGU - Ministério da Transparência e Controladoria Geral da União. (2017). Hackfest: CGU premia aplicativos de combate a corrupção. [Online] Available: http://www.cgu.gov.br/noticias/2017/08/hackfest-cgu-premia-aplicativos-de-combate-acorrupcao (January, 17, 2018).

Costa, A. D. J. B., Leite, D. B. A., \& Campos, E. S. (2015). Portais de transparência fiscal: uma crítica aos municípios com população entre 50 e 100 mil habitantes. Revista da FAE, 17(1), 24-61. 


\section{I Macrothink}

Journal of Public Administration and Governance ISSN 2161-7104 2018, Vol. 8, No. 3

ENAP - Escola Nacional Administração Pública. (2015). Controle Social: Módulo 1 Introdução e Conceitos Básicos.

IBGE - Instituto Brasileiro de Geografia Estatística. (2010). Cidades. [Online] Available: http://cidades.ibge.gov.br/xtras/uf.php?lang=\&coduf=15\&search=para. (January, 15,2018).

Lage, J. O. (2017). Controle Interno: Atuação na Contratação de Obras Públicas Municipais. [Online]

Available: https://jus.com.br/artigos/57313/o-controle-interno-atuacao-na-contratacao-de-obras-publicas -municipais (January, 24, 2018).

Matheus, R., Ribeiro, M. M., \& Vaz, J. C. (2012). New perspectives for electronic government in Brazil: The adoption of open government data in national and subnational governments of Brazil. ACM International Conference Proceeding Series, 22-29. https://doi.org/10.1145/2463728.2463734

Matias-Pereira, J. (2005). Reforma do Estado e controle da corrupção no Brasil. REGE. Revista de Gestão, 12(2), 1.

MEC - Ministério da Educação. FNDE - Fundo Nacional de Desenvolvimento da Educação. (2017). Sistema Integrado de Monitoramento e Controle (Simec). [Online] Available: http://www.fnde.gov.br/fnde_sistemas/simec. (November, 29, 2017).

O'Reilly, T. (2011). Government as a Platform. Innovations: Technology, Governance. Globalization, 6(1), 13-40. https://doi.org/10.1162/INOV_a_00056

Portal ORM. (2018), Má gestão domina 90\% das prefeituras do Pará. [Online] Available: http://noticias.orm.com.br/noticia3.asp?id=675687\&\%7Cm\%C3\%A1+gest\%C3\%A3o+domi n a+90\#.WmPcHa6nHIV (January, 13, 2018).

Santos, N. L. S. (2014). Corrupção no Brasil e a ineficácia dos instrumentos de controle: reflexos de uma cultura política patrimonialista. Revista Eletrônica de Ciência Política, 5(2), 150-170.

Siffert Filho, N. A. (1996). A teoria dos contratos econômicos e a firma. Tese de doutorado, Universidade de São Paulo, São Paulo, SP, Brasil.

Slomski, V. (2009). Controladoria e governança na gestão pública. Editora Atlas SA.

TCU - Tribunal de Contas da União. (2016). Aplicativo móvel aproxima o cidadão do Tribunal de Contas da União. [Online] Available: http://www.eufiscalizo.gov.br/2016/06/aplicativo-movel-aproxima-cidadao-do.html. (November, 29, 2017).

Transparência Brasil. (2017). Projetos: Tá de Pé?. [Online] Available: https://www.transparencia.org.br/projetos/tadepe. (November, 29, 2017).

UNDP - United Nations Development Program. (2006). Fighting corruption with egovernment application. 


\section{Copyright Disclaimer}

Copyright for this article is retained by the author(s), with first publication rights granted to the journal.

This is an open-access article distributed under the terms and conditions of the Creative Commons Attribution license (http://creativecommons.org/licenses/by/4.0/). 